\title{
(Arene)Ru(II) Complexes of P-N Ligands
}

\author{
S. D. Perera* \\ Department of Chemistry, the Open University of Sri Lanka, Nawala.
}

Ligands containing both phosphorus and nitrogen donors have shown excellent catalytic properties. We have set out to synthesize a series of P-N ligands known as "phosphino hydrazones". Some of these ligands, for example, $\left.\mathrm{Z}-\mathrm{PPh}_{2} \mathrm{CH}_{2} \mathrm{C}(\mathrm{Bu})^{t}\right)=\mathrm{NNMe}_{2} \boldsymbol{I}$ and $\mathrm{Z}-\mathrm{PPh}_{2} \mathrm{CH}_{2} \mathrm{C}\left(\mathrm{Bu}^{t}\right)=\mathrm{NNH}_{2}$ II have shown interesting coordination chemistry with transition metals such as $\mathrm{Cr}, \mathrm{Mo}, \mathrm{W}, \mathrm{Rh}, \mathrm{Ir}, \mathrm{Pd}$ and Pt. Here we report the synthesis of novel $\eta^{6-}$ arene complexes of $\boldsymbol{I}$ and $\boldsymbol{I I}$ with ruthenium. Treatment of 0.5 equivalent of $\left[\left(\eta^{6} \text {-p-cymene }\right) \mathrm{RuCl}_{2}\right]_{2}$ with $\mathbf{I}$ in refluxing benzene gave the ruthenium (II) complex (1). The chelating complex [( $\eta^{6}-p$-cymene $) \mathrm{RuCl}$ $\left.\left\{Z-P P h_{2} C_{2} C\left(B u^{t}\right)=N N M e_{2}\right\}\right] P F_{6}$ (2) with a 6 -membered ring was made by treating (1) with $\mathrm{NH}_{4} P \mathrm{~F}_{6}$ in methanol. Treatment of $\boldsymbol{I I}$ with 0.5 equiv. of $\left[\left(\eta^{6}-p \text {-cymene }\right) \mathrm{RuCl}_{2}\right]_{2}$ gave the chelating complex [( $\eta^{6}$-p-cymene $) \mathrm{RuCl}\{\mathrm{Z}$ $\left.\left.\mathrm{PPh}_{2} \mathrm{CH}_{2} \mathrm{C}\left(\mathrm{Bu} \mathrm{u}^{\mathrm{t}}\right)=\mathrm{NNH}_{2}\right\}\right] \mathrm{Cl}$ (3). We have found that the ligand $\mathbf{I}$ has the potential to act as either a modentate ligand or a bidentate ligand. The ligand II forms chelating complexes as the $\mathrm{NH}_{2}$ group is sterically less demanding.

\section{Introduction}

Recently, there has been a considerable interest in the use of P-N ligands to generate new coordination and organometallic chemistry. $\mathrm{P}-\mathrm{N}$ ligands contain at least one soft phosphorus donor and a hard nitrogen donor. Nitrogen donors are relatively good $\sigma$-donors but they do not act as $\pi$-acceptors. Thus, nitrogen donors do not prefer to coordinate to metal centres with low oxidation states. The coordination chemistry of phosphino hydrazones (e.g. $\left.Z-\mathrm{PPh}_{2} \mathrm{CH}_{2} \mathrm{C}\left(\mathrm{Bu}^{\mathrm{t}}\right)=\mathrm{NNR}^{1} \mathrm{R}^{2}\right)$ with Group 6, 8, 9 and 10 metal centres have been reported (Hii et al, 1992, Hii et al, 1994, Ike et al, 1998, Perera \& Shaw, 1995). This paper describes the syntheses of ( $p$-cymene) Ru(II)- complexes of the phosphino dimethylhydrazone $\mathrm{Z}-\mathrm{PPh}_{2} \mathrm{CH}_{2} \mathrm{C}\left(\mathrm{Bu}^{\mathrm{t}}\right)=\mathrm{NNMe}_{2}$ I and the phosphino hydrazone $\mathrm{Z}-\mathrm{PPh}_{2} \mathrm{CH}_{2} \mathrm{C}\left(\mathrm{Bu}^{\mathrm{t}}\right)=\mathrm{NNH}_{2}$ II .

The noteworthy features of these two ligands are (i) the $\mathrm{NMe}_{2}$ group is a better $\sigma$-donor than the $\mathrm{NH}_{2}$ group, and (ii) the $\mathrm{NMe}_{2}$ group is sterically more demanding than the $\mathrm{NH}_{2}$ group. (Arene)ruthenium(II)-complexes of several bidentate ligands have been reported (Davenport et al, 2000,

* Correspondence should be addressed to Prof. S. D. Perera, Department of Chemistry, the Open University of Sri Lanka (email: sarathperera@yahoo.com). 
Davies et al, 2001). Some examples include (i) asymmetric transfer hydrogenation of ketones, with enantiomeric excesses (ee) of $>99 \%$, using chiral diamine ligands (Noyori \& Hashiguchi, 1997); (ii) asymmetric hydrogenation with [RuCl(binap)(arene) $]^{+}$(Mashima, et al, 1989)]; (iii) enantioselective Diels-Alder reactions catalysed by [RuCl(pyridyloxazoline)(arene)][ $\left.\mathrm{SbF}_{6}\right]$ (Davenport, et al, 2000).

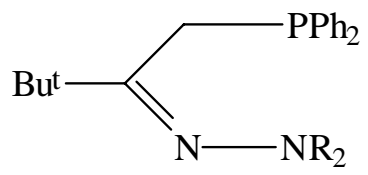

$\mathrm{R}$

I $\mathrm{Me}$

II $\mathrm{H}$

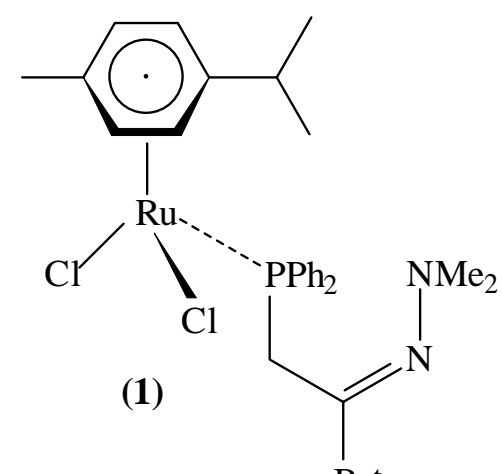

$\mathrm{Bu}^{\mathrm{t}}$

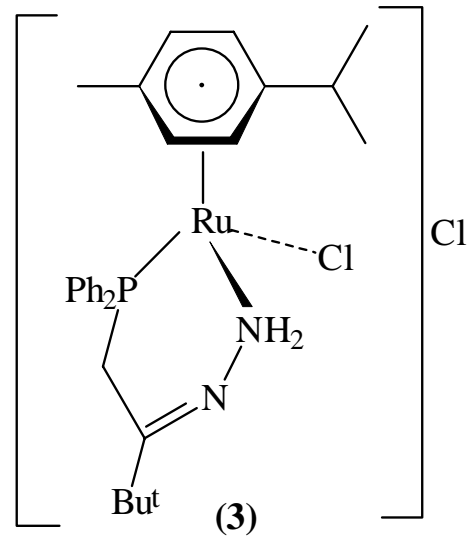

(2)

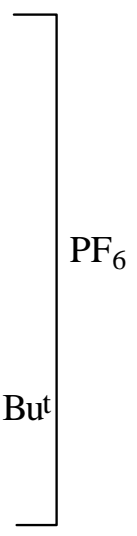

$\mathrm{PF}_{6}$

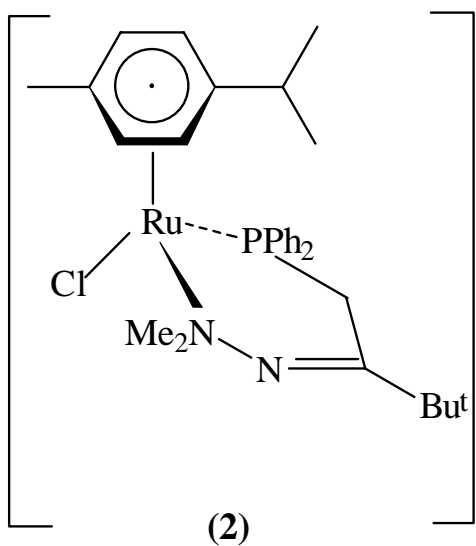

\section{Experimental}

All the reactions were carried out in an inert atmosphere of dry nitrogen or dry argon. NMR spectra were recorded using a Bruker ARX250 spectrometer (operating frequencies for ${ }^{1} \mathrm{H},{ }^{31} \mathrm{P}$ and ${ }^{13} \mathrm{C}$ are 250.6 , 101 and $62.9 \mathrm{MHz}$, respectively) or a Bruker AM-400 spectrometer (operating frequencies for ${ }^{1} \mathrm{H},{ }^{31} \mathrm{P}$ and ${ }^{13} \mathrm{C}$ are $400.1,161.9$ and 100.6 $\mathrm{MHz}$, respectively). ${ }^{1} \mathrm{H}$ and ${ }^{13} \mathrm{C}$ chemical shifts are relative to 
tetramethylsilane and ${ }^{31} \mathrm{P}$ shifts are relative to $85 \%$ phosphoric acid. Infrared spectra were recorded using a Perkin-Elmer model 257 grating spectrometer $\left(4000-600 \mathrm{~cm}^{-1}\right)$ or a Pye Unicam SP2000 $\left(4000-200 \mathrm{~cm}^{-1}\right)$. Mass spectra were recorded on a VG Autospec mass spectrometer using $8 \mathrm{kV}$ acceleration. For metal complexes, the $m / z$ values are quoted for ${ }^{102} \mathrm{Ru}$ and ${ }^{35} \mathrm{Cl}$.

\section{$\left[\left\{\eta^{6}-\mathrm{p}-\mathrm{MeC}_{6} \mathrm{H}_{4} \mathrm{CH}(\mathrm{Me})_{2}\right\} \mathrm{RuCl}_{2}\left\{\mathrm{PPh}_{2} \mathrm{CH}_{2} \mathrm{C}\left(\mathrm{Bu}^{\mathrm{t}}\right)=\mathrm{NNMe}_{2}\right\}\right]$ (1).}

A mixture of [( $\eta^{6}$-p-cymene $\left.) \mathrm{RuCl}_{2}\right]_{2}$ [5] $(0.23 \mathrm{~g}, 0.38 \mathrm{mmol})$ and the phosphino dimethylhydrazone $\mathbf{I}(0.25 \mathrm{~g}, 0.76 \mathrm{mmol})$ in benzene $(3 \mathrm{~mL})$ was heated under reflux for $35 \mathrm{~min}$. The complex (1) crystallized as red microcrystals, $(0.43 \mathrm{~g}, 89 \%)$. (Found: $\mathrm{C}, 58.7 ; \mathrm{H}, 6.45 ; \mathrm{Cl}, 10.6 ; \mathrm{N}, 4.0$. $\mathrm{C}_{30} \mathrm{H}_{41} \mathrm{Cl}_{2} \mathrm{~N}_{2} \mathrm{PRu} .0 .5 \mathrm{C}_{6} \mathrm{H}_{6}$ requires $\mathrm{C}, 59.0 ; \mathrm{H}, 6.6 ; \mathrm{Cl}, 10.55 ; \mathrm{N}, 4.15 \%$ ). Mass (FAB): $\mathrm{m} / \mathrm{z} 632\left(\mathrm{M}^{+}\right)$and 597 (M-Cl). IR (Nujol): $\mathrm{v}(\mathrm{Ru}-\mathrm{Cl})=280$ $\mathrm{cm}^{-1} \cdot{ }^{31} \mathrm{P}-\left\{{ }^{1} \mathrm{H}\right\}$ NMR $\left(101 \mathrm{MHz}, \mathrm{CDCl}_{3}\right), \delta_{\mathrm{P}}(\mathrm{ppm}): 22.7$ (s). ${ }^{1} \mathrm{H}-\mathrm{NMR}(250$ $\left.\mathrm{MHz}, \mathrm{CDCl}_{3}\right), \delta_{\mathrm{H}}(\mathrm{ppm}): 0.56\left(9 \mathrm{H}, \mathrm{s}, \mathrm{Bu}^{\mathrm{t}}\right), 1.11\left[6 \mathrm{H}, \mathrm{d},{ }^{3} \mathrm{~J}(\mathrm{HH}) 6.9\right.$, $\mathrm{CHMe}_{2}$ ], $1.67\left(3 \mathrm{H}, \mathrm{s}, 4-\mathrm{MeC}_{6} \mathrm{H}_{4}\right), 1.84(6 \mathrm{H}, \mathrm{s}, \mathrm{NMe}), 2.44(1 \mathrm{H}, \mathrm{m}$, $\left.\mathrm{CHMe}_{2}\right)$ and $3.61\left[2 \mathrm{H}, \mathrm{d},{ }^{2} \mathrm{~J}(\mathrm{PH}) 13.0, \mathrm{CH}_{2} \mathrm{P}\right] .{ }^{13} \mathrm{C}-\left\{{ }^{1} \mathrm{H}\right\} \mathrm{NMR}(62.9 \mathrm{MHz}$, $\left.\mathrm{CDCl}_{3}\right) \delta_{\mathrm{C}}(\mathrm{ppm}): 17.3\left(1 \mathrm{C}, \mathrm{s}, 4-\mathrm{MeC}_{6} \mathrm{H}_{4}\right), 22.2(2 \mathrm{C}, \mathrm{s}, \mathrm{CHMe}), 24.6$ [1C, d, ${ }^{1} \mathrm{~J}(\mathrm{PC}) 19.6, \mathrm{CH}_{2} \mathrm{P}$ ], 28.0 (3C, s, $\left.\mathrm{CMe}_{3}\right), 30.1$ (1C, s, $\mathrm{CHMe}_{2}$ ), 39.3 [1C, d, $\left.3 \mathrm{~J}(\mathrm{PC}) 1.6, \mathrm{CMe}_{3}\right], 45.5(2 \mathrm{C}, \mathrm{s}, \mathrm{NMe})$ and 172.9 [1C, d, ${ }^{2} \mathrm{~J}(\mathrm{PC})$ 13.6, $C=\mathrm{N}]$.

\section{$\left[\left\{n^{6}-\mathrm{MeC}_{6} \mathrm{H}_{4} \mathrm{CH}(\mathrm{Me})_{2}\right\} \mathrm{RuCl}\left\{\mathrm{PPh}_{2} \mathrm{CH}_{2} \mathrm{C}\left(\mathrm{Bu}^{\mathrm{t}}\right)=\mathrm{NNM} \mathrm{N}_{2}\right\}-\mathrm{P}, \mathrm{N}\right] \mathrm{PF}_{6}$ (2).}

A mixture of (1) (50 mg, $0.08 \mathrm{mmol})$ and of $\mathrm{NH}_{4} \mathrm{PF}_{6}(12 \mathrm{mg}, 0.08 \mathrm{mmol})$ in methanol $(3 \mathrm{~mL})$ was heated at $\mathrm{ca} .60{ }^{\circ} \mathrm{C}$ for $15 \mathrm{~min}$. The required product (2) crystallized as orange microcrystals and was collected.

Yield (34 mg, 58\%). (Found: C, 49.0; H, 5.6; Cl, 4.9; N, 3.85.

$\mathrm{C}_{30} \mathrm{H}_{41} \mathrm{ClF}_{6} \mathrm{~N}_{2} \mathrm{P}_{2} \mathrm{Ru}$ requires $\mathrm{C}, 48.55 ; \mathrm{H}, 5.55 ; \mathrm{Cl}, 4.8 ; \mathrm{N}, 3.8 \%$ ). Mass (FAB): $\mathrm{m} / z 597\left(\mathrm{M}^{\mathrm{P}} \mathrm{PF}_{6}\right)$. IR (Nujol): $\mathrm{v}(\mathrm{Ru}-\mathrm{Cl})=290 \mathrm{~cm}^{-1} \cdot{ }^{31} \mathrm{P}-\left\{{ }^{1} \mathrm{H}\right\} \mathrm{NMR}$ (101 MHz, $\left.\mathrm{CDCl}_{3}\right), \delta_{\mathrm{P}}(\mathrm{ppm}): 52.4$ (s). ${ }^{1} \mathrm{H}-\mathrm{NMR}\left(250 \mathrm{MHz}, \mathrm{CDCl}_{3}\right), \delta_{\mathrm{H}}$ (ppm): $\left.0.82(9 \mathrm{H}, \mathrm{s}, \mathrm{CMe})_{3}\right), 1.16\left[6 \mathrm{H}, \mathrm{d}, 3 \mathrm{~J}(\mathrm{HH}) 7.0, \mathrm{CHMe} e_{2}\right], 1.19(3 \mathrm{H}, \mathrm{s}$, 4- $\left.\left.\mathrm{MeC}_{6} \mathrm{H}_{4}\right), 1.21\left(3 \mathrm{H}, \mathrm{s}, \mathrm{N} M e_{2}\right), 1.22(3 \mathrm{H}, \mathrm{s}, \mathrm{NMe} 2), 2.53(1 \mathrm{H}, \mathrm{m}, \mathrm{CHMe})_{2}\right)$ $2.59\left[1 \mathrm{H}, \mathrm{dd},{ }^{2} \mathrm{~J}(\mathrm{PH}) 10.6,{ }^{2} \mathrm{~J}(\mathrm{HH}) 16.2, \mathrm{CH}_{2} \mathrm{P}\right]$ and $3.47\left[1 \mathrm{H}, \mathrm{t},{ }^{2} \mathrm{~J}(\mathrm{PH})=\right.$ $\left.{ }^{2} \mathrm{~J}(\mathrm{HH}) 16.2, \mathrm{CH}_{2} \mathrm{P}\right] .{ }^{13} \mathrm{C}-\left\{{ }^{1} \mathrm{H}\right\} \mathrm{NMR}\left(62.9 \mathrm{MHz}, \mathrm{CDCl}_{3}\right) \delta_{\mathrm{C}}(\mathrm{ppm}): 18.2(1 \mathrm{C}$, s, $\left.\mathrm{CH}_{3}\right), 19.9$ [1C, d, ${ }^{1} \mathrm{~J}(\mathrm{PC}) 21.2, \mathrm{CH}_{2} \mathrm{P}$ ] $22.8(2 \mathrm{C}, \mathrm{s}, \mathrm{CHMe}), 27.4$ (3C, $\left.\mathrm{s}, \mathrm{CMe}_{3}\right), 30.4\left(1 \mathrm{C}, \mathrm{s}, \mathrm{CHMe}_{2}\right), 39.5\left[1 \mathrm{C}, \mathrm{d},{ }^{3} \mathrm{~J}(\mathrm{PC}) 2.4, \mathrm{CMe}_{3}\right], 45.5(2 \mathrm{C}$, $\mathrm{s}, \mathrm{NMe})$ and $170.8(1 \mathrm{C}, \mathrm{s}, C=\mathrm{N})$. 


\section{$\left[\left\{\eta^{6}-\mathrm{p}-\mathrm{CH}_{3} \mathrm{C}_{6} \mathrm{H}_{4} \mathrm{CH}(\mathrm{Me})_{2}\right\} \mathrm{RuCl}\left\{\underline{\mathrm{PPh}} \mathrm{CH}_{2} \mathrm{C}\left(\mathrm{Bu}^{\mathrm{t}}\right)=\mathrm{NNH}_{2}\right\}-\mathrm{P}, \mathrm{N}\right] \mathrm{Cl}$ (3).}

A mixture of $\left[\left(\eta^{6}-p \text {-cymene }\right) \mathrm{RuCl}_{2}\right]_{2}(50 \mathrm{mg}, 0.08 \mathrm{mmol})$ and the phosphino hydrazone II $(49 \mathrm{mg}, 0.16 \mathrm{mmol})$ in benzene $(1.5 \mathrm{~mL})$ was heated at $\mathrm{ca} .60{ }^{\circ} \mathrm{C}$ for $5 \mathrm{~min}$. The complex (3) crystallized out immediately as yellow microcrystals. It was collected and washed with ether. Yield (67 mg, 69\%). (Found: C, 55.1; H, 5.9; Cl, 11.55; N, 4.45. $\mathrm{C}_{28} \mathrm{H}_{37} \mathrm{Cl}_{2} \mathrm{~N}_{2} \mathrm{PRu}$ requires $\left.\mathrm{C}, 55.6 ; \mathrm{H}, 6.15 ; \mathrm{Cl}, 11.7 ; \mathrm{N}, 4.65 \%\right)$. Mass (FAB): $\mathrm{m} / \mathrm{z} 569$ (M-Cl) and 533 (M-Cl-HCl). IR (Nujol): $\mathrm{v}(\mathrm{Ru}-\mathrm{Cl})=275$ $\mathrm{cm}^{-1} .{ }^{31} \mathrm{P}-\{1 \mathrm{H}\}$ NMR $\left(101 \mathrm{MHz}, \mathrm{CDCl}_{3}\right), \delta_{\mathrm{P}}(\mathrm{ppm}): 60.8$ (s). ${ }^{1} \mathrm{H}-\mathrm{NMR}(250$ $\left.\mathrm{MHz}_{\mathrm{CDCl}}\right), \delta_{\mathrm{H}}(\mathrm{ppm}): 0.80\left(9 \mathrm{H}, \mathrm{s}, \mathrm{Bu}^{\mathrm{t}}\right), 1.13$ [3H, d, 3J (HH) 6.8, $\mathrm{CHMe}_{2}$ ], 1.30 [3H, d, 3J (HH) 6.8, CHMe ${ }_{2}$ ], $2.26\left(3 \mathrm{H}, \mathrm{s}, 4-\mathrm{MeC}_{6} \mathrm{H}_{4}\right), 2.85$ $\left(1 \mathrm{H}, \mathrm{m}, \mathrm{d}, 3 \mathrm{~J}(\mathrm{HH}) 6.8, \mathrm{CHMe}_{2}\right), 3.36\left[1 \mathrm{H}, \mathrm{t},{ }^{2} \mathrm{~J}(\mathrm{HH})=2 \mathrm{~J}(\mathrm{PH}) 14.0\right.$, $\left.\mathrm{CH}^{2} \mathrm{P}\right], 3.81\left[1 \mathrm{H}, \mathrm{t},{ }^{2} \mathrm{~J}(\mathrm{HH})=2 \mathrm{~J}(\mathrm{PH}) 14.0, \mathrm{CH}_{2} \mathrm{P}\right], 10.10\left(1 \mathrm{H}, \mathrm{t},{ }^{2} \mathrm{~J}(\mathrm{HH})=\right.$ ${ }^{3} \mathrm{~J}(\mathrm{PH})$ 9.9, $\left.\mathrm{NH}_{2}\right) \cdot{ }^{13} \mathrm{C}-\left\{{ }^{1} \mathrm{H}\right\}\left(101 \mathrm{MHz}, \mathrm{CDCl}_{3}\right), \mathrm{NMR}\left(62.9 \mathrm{MHz}, \mathrm{CDCl}_{3}\right) \delta_{\mathrm{C}}$ (ppm): 18.2 (1C, s, $\left.\mathrm{CH}_{3}\right), 22.3\left(1 \mathrm{C}, \mathrm{s}, \mathrm{CH}_{3}\right), 22.8$ (1C, s, $\left.\mathrm{CH}_{3}\right), 25.0$ [1C, d, $\left.{ }^{1} \mathrm{~J}(\mathrm{PC}) 18.1, \mathrm{CH}_{2} \mathrm{P}\right], 27.4(3 \mathrm{C}, \mathrm{s}, \mathrm{CMe}), 30.4\left(1 \mathrm{C}, \mathrm{s}, \mathrm{CHMe}_{2}\right), 39.5$ [1C, $\left.\mathrm{d},{ }^{3} \mathrm{~J}(\mathrm{PC}) 2.4, \mathrm{CMe}_{3}\right]$, and $172.9\left[1 \mathrm{C}, \mathrm{d},{ }^{2} \mathrm{~J}(\mathrm{PC}) 3.0, C=\mathrm{N}\right]$.

\section{Results and Discussion}

Treatment of 0.5 equivalent of $\left[\left(\eta^{6}-p \text {-cymene }\right) \mathrm{RuCl}_{2}\right]_{2}$ with the ligand $\mathbf{I}$ in refluxing benzene gave the ruthenium (II) complex (1) as red microcrystals in $89 \%$ yield. Micro-analytical data and mass spectral data suggest that the complex (1) is with the composition $\left[\mathrm{RuCl}_{2}(p-\right.$ cymene) $\left.\left\{\mathrm{PPh}_{2} \mathrm{CH}_{2} \mathrm{C}\left(\mathrm{Bu}^{\mathrm{t}}\right)=\mathrm{NNMe}_{2}\right\}\right]$. In the mass spectrum, the parent ion gave a profile at $\mathrm{m} / \mathrm{z} 632$ Dalton. The ${ }^{31} \mathrm{P}-\left\{{ }^{1} \mathrm{H}\right\}$ NMR spectrum showed a singlet at $22.7 \mathrm{ppm}$. The low-field shift of $32.4 \mathrm{ppm}\left(\delta_{\mathrm{p}}\right.$ of the free ligand $\mathbf{I}$ is $-9.7 \mathrm{ppm}$ ) of the phosphorus chemical shift indicates the coordination of $\mathrm{PPh}_{2}$ group to Ru centre. In the proton NMR spectrum, the tert-butyl and $\mathrm{NMe}_{2}$ groups gave singlets at 0.56 and $1.84 \mathrm{ppm}$. The two protons of the $\mathrm{CH}_{2} \mathrm{P}$ group were chemically equivalent and appeared as a doublet at $3.61 \mathrm{ppm},{ }^{2} \mathrm{~J}(\mathrm{PH})=13.0 \mathrm{~Hz}$. The two-methyl groups of the isopropyl group of the $p$-cymene ligand gave a doublet at $1.11 \mathrm{ppm}$ with a ${ }^{3} \mathrm{~J}(\mathrm{HH})$ value of $6.9 \mathrm{~Hz}$. In this red complex (1), the ligand $\mathbf{I}$ is coordinated to the $\mathrm{Ru}(\mathrm{II})$ centre in a monodentate fashion through the P-donor as indicated by the characterizing data. This phosphino dimethylhydrazone ligand I formed chelating complexes readily with a number of metal centres (Hii et al, 1992, Hii et al, 1994, Ike et al, 1998, Perera \& Shaw, 1995). We hoped that the ligand I in the complex (1) could form a six-membered chelate ring by removing 
one of the chloride ligands. The orange chelating complex $\left[\left(\eta^{6}-p-\right.\right.$ cymene $\left.) \mathrm{RuCl}\left\{\mathrm{Z}-\mathrm{PPh}_{2} \mathrm{CH}_{2} \mathrm{C}\left(\mathrm{Bu}^{\mathrm{t}}\right)=\mathrm{NNMe}_{2}\right\}\right] \mathrm{PF}_{6}$ (2) with a six-membered ring was prepared by treating the complex (1) with $\mathrm{NH}_{4} \mathrm{PF}_{6}$ in methanol. As expected, the phosphorus-31 resonance showed a large low field shift and appeared at $52.4 \mathrm{ppm}$. The two protons of the $\mathrm{CH}_{2} \mathrm{P}$ group are now not chemically equivalent and in the ${ }^{1} \mathrm{H}-\left\{{ }^{1} \mathrm{P}\right\}$ NMR spectrum they showed a $A B$ pattern with $3 \mathrm{~J}(\mathrm{HH})=16.2 \mathrm{~Hz}$. Treatment of the ligand II with 0.5 equivalent of $\left[\left(\eta^{6}-p \text {-cymene }\right) \mathrm{RuCl}_{2}\right]_{2}$ gave the chelating complex $\left[\left(\eta^{6}-p\right.\right.$-cymene $\left.) \mathrm{RuCl}\left\{\mathrm{Z}-\mathrm{PPh}_{2} \mathrm{CH}_{2} \mathrm{C}\left(\mathrm{Bu}^{t}\right)=\mathrm{NNH}_{2}\right\}\right] \mathrm{Cl}$ (3) as yellow microcrystals in $69 \%$ yield. The spectral data are in good agreement with the proposed structure, where the sterically less demanding $\mathrm{NH}_{2}$ group prefers to be coordinated to the ruthenium centre by displacing a chloride ligand.

\section{Acknowledgements}

Author wishes to thank the University of Leeds for a Research Fellowship, and Professor Bernard Shaw for other support.

\section{References}

Hii, K. K., Perera, S. D., Shaw, B. L. \& Thornton-Pett, M. (1992). New bidentate ligands of the types $\mathrm{PPh} 2 \mathrm{CH} 2 \mathrm{C}(\mathrm{But})=\mathrm{NNR} 2(\mathrm{R}=\mathrm{H}$ or Me) and $\mathrm{PPh} 2 \mathrm{CH} 2 \mathrm{C}(\mathrm{But})=\mathrm{N}-\mathrm{N}=\mathrm{CHPh}$ and their complexes with group 6 metal carbonyls.Journal of the Chemical Society, Dalton Transactions. pp2361.

Ike, U. U., Perera, S. D., Shaw, B. L. \& Thornton-Pett, M. (1998). Some chloro carbonylruthenium(II) complexes of $\mathrm{P}, \mathrm{N}$-donor ligands: Crystal structures of $[\mathrm{RuCl}(\mathrm{CO})\{\mathrm{PPh} 2 \mathrm{CH} 2 \mathrm{C}(\mathrm{But})=\mathrm{NNH} 2\} 2] \mathrm{Cl}$ and fac, cis$[\mathrm{RuCl} 2(\mathrm{CO})\{\mathrm{PPh} 2 \mathrm{CH} 2 \mathrm{C}(\mathrm{But})=\mathrm{N}-\mathrm{N}=\mathrm{C}(\mathrm{But}) \mathrm{CH} 2 \mathrm{PPh} 2\}]$. Inorganica. Chimica. Acta, 279, pp-95.

Perera, S. D. \& Shaw, B. L., (1995). Complexes of the bidentate ligands $\mathrm{Z}-\mathrm{PPh} 2 \mathrm{CH} 2 \mathrm{C}(\mathrm{But})=\mathrm{NNR} 2(\mathrm{R}=\mathrm{H}$ or $\mathrm{Me})$ with $\mathrm{Rh}$ and Ir. Journal of the Chemical Society, Dalton Transactions, pp-633.

Hii, K. K., Perera, S. D., Shaw, B. L. \& Thornton-Pett, M., (1994). Complexes of the bidentate ligands $\mathrm{PPh} 2 \mathrm{CH} 2 \mathrm{C}(\mathrm{But})=\mathrm{NNR} 2(\mathrm{R}=\mathrm{H}, \mathrm{Me})$ and $\mathrm{PPh} 2 \mathrm{CH} 2 \mathrm{C}(\mathrm{But})=\mathrm{N}-\mathrm{N}=\mathrm{CHPh}$ with $\mathrm{Pd}(\mathrm{II})$ and $\mathrm{Pt}(\mathrm{II})$. Crystal structure of cis- $[\mathrm{Pt}\{\mathrm{PPh} 2 \mathrm{CH} 2 \mathrm{C}(\mathrm{But})=\mathrm{NNH}\} 2]$. Journal of the Chemical Society, Dalton Transactions, pp-103. 
Davies, D. L., Fawcett, J., Garratt, S. A., \& Russell, D. R. (2001).

(Arene)ruthenium complexes with bis(oxazolines): Synthesis and applications as assymetric catalysts for Diels-Alder reactions.

Organometallics, 20, pp-3029.

Davenport, A. J., Davies, D. L., Fawcett, J., Garratt, S. A., \& Russell D. R., (2000). Arene ruthenium complexes with pyridyloxozolines: Synthesis and applications as assymetric catalysts for Diels-Alder reactions. Journal of the Chemical Society, Dalton Transactions, pp-4432.

Noyori, R. \& Hashiguchi, (1997). Asymmetric transfer hydrogenation catalysed by chiral ruthenium complexes. Accounts of Chemical Research, 30, pp-97.

Mashima, K., Kusano, K., Ohta, T., Noyori, R., \& Takaya, H., (1989). Synthesis of new cationic BINAP-ruthenium(II) complexes and their use in aymmetric hydrogenation. Journal of the Chemical Society, Chemical Communication, pp-1208. 